\title{
Zagraniczne inspiracje dla kultury zdrowotnej szkoły polskiej na łamach czasopism medycznych i pedagogicznych w Drugiej Rzeczypospolitej Polskiej
}

\section{Wprowadzenie terminologiczne}

Pojęcie kultury zdrowotnej pojawiło się u progu niepodległości Polski i użyte zostało w wydanej w 1917 r. pracy, którą napisał Kazimierz Sosnowski. Nosiła ona znamienny tytuł Szkoła jako krzewicielka kultury zdrowotnej i energii twórczej'.

W rozumieniu tego autora kultura zdrowotna była zadaniem szkoły polegającym na wzmacnianiu zdrowia swych wychowanków oraz przeciwdziałaniu zagrożeniom ich zdrowia. „Zdrowa szkoła” poprzez „zdrowych uczniów” spełniać miała swój obowiązek na rzecz zdrowia publicznego, a więc - jak określił K. Sosnowski - „krzewić za ich pośrednictwem kulturę zdrowotną”2. Indywidualny wymiar zdrowia ucznia zyskiwał w ten sposób walor społeczny. Było to szczególnie ważne w Polsce, gdyż jak uznawał wspomniany autor „Stopień zdrowotności publicznej w narodzie polskim jest niski”, a ponadto „[... [ reorganizacja zdrowotności musi zacząć się od szkoły, a przez szkołę wtargnąć w wychowanie domowe i w ten sposób stanie się powszechną"4.

${ }^{*}$ Dr, Katedra Historii Wychowania i Pedeutologii, Wydział Nauk o Wychowaniu, Uniwersytet Łódzki, 91-408 Łódź, ul. Pomorska 46/48.

${ }^{1}$ K. S o s n o w s k i, Szkoła jako krzewicielka kultury zdrowotnej i energii twórczej, Wydawnictwo Akademii Handlowej, Kraków 1917. Podano za: t e n ż e, Szkoła a zdrowie, wyd. 2, Akademia Handlowa w Krakowie, Kraków-Warszawa 1920, s. 3. Por. J. B ą c z k i e w i c z, Szkoła jako krzewicielka higieny praktycznej, „Zdrowie” [dalej: Z] 1913, s. 152; M. T h e m e r s o n, O krzewieniu kultury higienicznej przez szkoły początkowe, tamże, s. 36.

${ }^{2}$ K. S o s n o w s k i, Szkoła a zdrowie, s. 72.

${ }^{3}$ Tamże, s. 23.

${ }^{4}$ Tamże, s. 67. 
Widzenie szkoły jako instytucji transferującej wiedzę o zdrowiu i przyzwyczajeniach higienicznych do rodziny ucznia oraz otoczenia społecznego pozostało obecne i wzmocnione w poglądach wielu autorów po odzyskaniu przez Polskę niepodległości.

W Polsce w okresie dwudziestolecia międzywojennego dla oznaczenia tak działań profilaktycznych, jak i ich efektów prozdrowotnych, dokonujących się „w szkole i poprzez szkołę" - częściej jednak używano pojęcia higiena szkolna, wskazując jako jej działy: budynek szkolny i jego wyposażenie, rozwój fizyczny oraz psychiczny dzieci i młodzieży, choroby szkolne, ogólne zasady wychowania fizycznego w szkole, zasady organizacji procesu nauczania, kształcenie dzieci anormalnych, organizację dozoru lekarsko-higienicznego w szkole ${ }^{5}$. Zakres tego pojęcia był więc bardzo obszerny.

W wydanym na początku lat dwudziestych podręczniku higieny szkolnej Stanisław Kopczyński mocno pokreślił indywidualny i społeczny aspekt szerzenia zdrowia w szkole i przez szkołę: „Szkoła powinna służyć do celów propagandy higieny. Już wzorowy lokal szkolny jest praktyczną szkołą higieny, poza tem jednak wdrażanie dzieci przez szkołę do zwyczajów higienicznych, uświadamianie dzieci teoretycznie w zasadach higieny uczynić może z uczniów pionierów podstaw zdrowotnych, na jakich siły i zdrowie społeczeństwa opierać się powinny"6.

Natomiast Marcin Kacprzak w zbliżony do S. Kopczyńskiego sposób określił higienę szkolną jako: „[...] całokształt zagadnień zdrowotnych dotyczących szkoły [...]"' . Autor ten uznawał szkołę nie tylko za najodpowiedniejszą, ale traktował ją jako jedyną instytucję, która ma „[...] zasady higieniczne wpoić w ogół mas obywatelskich, by one chciały je stosować, żyć według nich"8. Z kolei O. Anzelm mocno podkreślał, że wobec niskiego poziomu uświadomienia higienicznego ludności w Polsce w porównaniu do Europy Zachodniej należy wykorzystać, w celu dorównania sąsiadom, wszelkie nadarzające się możliwości, a wśród nich przede wszystkim oddziaływanie szkoły ${ }^{9}$.

Pojęcie kultury zdrowotnej występowało w literaturze II Rzeczypospolitej Polskiej dość sporadycznie, a stało się częściej używanym w latach siedemdziesiątych dwudziestego wieku.

${ }^{5}$ S. K o p c z y ń s k i (red.), Higiena szkolna. Podręcznik zbiorowy dla kierowników szkół, nauczycieli i lekarzy szkolnych, Wydawnictwo M. Arcta w Warszawie, Warszawa, Poznań, Lwów, Lublin, Łódź, Wilno 1921, s. 1-4.

6 Tamże [Wszystkie cytaty w tym artykule zachowały oryginalną pisownię.], s. 3.

7 M. K a c p r z a k, Współczesne poglądy na higienę szkolną, „Praca i Opieka Społeczna” 1933, nr 3, s. 247.

8 Tamże.

9 O. A n z e I m, O propagandzie higieny, Z 1931, nr 15-16, s. 879. 


\section{Początki obecności tematyki zagranicznej w obszarze kultury zdrowotnej szkoły na łamach polskich czasopism}

Pojawianie się artykułów dotyczących zagranicznych koncepcji i rozwiązań praktycznych z zakresu kultury zdrowotnej szkoły na łamach polskiego czasopiśmiennictwa dostrzec można w drugiej połowie XIX w.; odzwierciedla ono postępujący rozwój higieny szkolnej, jak i wpływ idei „Nowego Wychowania”.

Wśród publikacji w ramach tej problematyki znaleźć można przede wszystkim pozycje dotyczące oceny sytuacji zdrowotnej panującej w szkołach - z dużym naciskiem na elementy materialnego środowiska szkoły (budynek szkolny, jego wyposażenie i otoczenie), stanu zdrowia uczniów i sposobów jego badania, szkolnej opieki lekarsko-higienicznej i jej realizatorów, zagrożeń zdrowia uczniów, w tym chorób - zwłaszcza gruźlicy - „przeciążenia szkolnego” oraz spożywania alkoholu, pracy dydaktyczno-wychowawczej szkoły w aspektach mających wpływ na zdrowie uczniów.

W zestawieniu bibliograficznym polskiego piśmiennictwa z lat 1867-1921, liczącym ponad 600 pozycji, które przedstawił w podręczniku higieny szkolnej na początku lat dwudziestych S. Kopczyński, wśród ok. 400 artykułów znalazło się co najmniej ok. 30 związanych z kulturą zdrowotną szkoły w innych, głównie europejskich, krajach ${ }^{10}$. Oznacza to dużą przewagę liczebną publikacji prasowych dotyczących polskich realiów, koncepcji, organizacji i praktyki higieny szkolnej.

Prace z zakresu zagadnień kultury zdrowotnej szkoły spoza obszaru ziem polskich prezentowane były na łamach zarówno czasopism medycznych, to jest: „Przeglądu Lekarskiego”, „Przeglądu Higienicznego”, „Medycyny”, „Zdrowia”, jak i pedagogicznych, a wśród nich: „Wychowania w Domu i w Szkole”, „Przeglądu Pedagogicznego”, „Muzeum”, „Nowych Torów”, „Czasopisma Pedagogicznego”11.

W ramach łączności ze światowym ruchem naukowym przedstawiano na łamach prasy sprawozdania z Międzynarodowych Zjazdów Higieny Szkolnej. Pierwszy z nich miał miejsce w Norymberdze w 1904 r. $^{12}$

Kolejne kongresy odbywały się w Londynie - 1907 r. ${ }^{13}$, Paryżu - 1910 r. ${ }^{14}$

${ }^{10}$ S. Ko p c z y ń s k i (red.), Higiena szkolna..., s. 784-804. Pierwszy wśród zebranych przez S. Kopczyńskiego artykuł dotyczący higieny szkolnej, opublikowany na ziemiach polskich to: W. W o łe k, O poprawie ław szkolnych, „Rocznik Towarzystwa Technicznego”, Lwów 1867, s. 1.

11 Ostatnie z wymienionych czasopism, wydawane w Galicji, nie zostało uwzględnione w zestawieniu bibliograficznym sporządzonym przez S. Kopczyńskiego, choć stanowić może jednak cenne źródło do badań w tym obszarze tematycznym.

12 Por. Bericht über den I. Internationalen Kongress für schule-hygiene, Nürnberg, J. L. Schrag, 1904; F. E. B a t t e n, First International Congress of School Hygiene, Nürnberg, April 1904.

${ }^{13}$ Konferencja poświęcona higienie szkolnej w Londynie, „Muzeum” 1905, s. 424. Por. The Second International Congress on School Hygiene, London 1907. Transactions vol. I-III, The Royal Sanitary Institute, 1908; International Congress on School Hygiene, „The British Medical Journal" 1907, 10 August, s. 352-355.

14 Udział Polski w III Międzynarodowym Kongresie higienistów szkolnych w Paryżu, „Muzeum” 1909, s. 246; 1910, s. 221, 552; III. Zjazd Międzynarodowy w sprawie higieny szkolnej w Paryżu, „Wychowanie w Domu i Szkole” 1910, s. 680. Por. T. F. Harrington, Third International Congress on 
Prezentowano także sprawozdania z Międzynarodowej Wystawy Higienicznej w Dreźnie w 1911 r. ${ }^{15}$

Trudno jednak na łamach prasy polskiej odnaleźć informacje o obradach ostatniego przed wybuchem I wojny światowej - IV Międzynarodowego Kongresu Higieny Szkolnej, który odbył się poza kontynentem europejskim w Buffalo w 1913 r., choć - podobnie jak we wszystkich poprzednich - uczestniczył w nim jako członek Stałego Komitetu - S. Kopczyński, a w ramach Komitetu Polskiego znaleźć można nazwiska ok. 50 Polaków ${ }^{16}$. Członkowie tego Komitetu pochodzili zarówno z ziem polskich pod zaborami, jak i wywodzili się z kręgu Polonii amerykańskiej; reprezentowali oni ośrodki uniwersyteckie - głównie Lwów i Kraków ${ }^{17}$; wielu było wśród nich pedagogów-nauczycieli zrzeszonych w polskich organizacjach związkowych ${ }^{18}$ oraz przedstawicieli władz szkolnych i medycznych. Sam S. Kopczyński wspominał, iż „Tematy poruszane na tych zjazdach, były przedmiotem niejednokrotnych obrad w naszych towarzystwach lekarsko-pedagogicznych"19. Możliwe, że wybuch I wojny światowej i związane z nim nadzieje Polaków na odzyskanie niepodległości i utworzenie własnego państwa spowodowały wyparcie zainteresowania treścią obrad kongresu w Buffalo i silniejszą koncentrację na rodzimym gruncie ${ }^{20}$.

Spora część artykułów dotyczyła zagranicznych rozwiązań w zakresie szkolnej opieki higieniczno-lekarskiej nad zdrowiem dzieci i młodzieży ${ }^{21}$.

School Hygiene, Paris 1910, [w:] Reports on International Congress by American Delegates, Advance Sheets United States Bureau of Educations, s. 589-598.

${ }^{15}$ H. H i g i e r, Higiena szkolna na Międzynarodowej Wystawie Higienicznej w Dreźnie 1911 r., Z 1912, s. 51, 122; Z wystawy higienicznej w Dreźnie, „Czasopismo Pedagogiczne” 1912, s. 118-120.

${ }^{16}$ Por. G. M. W h i p ple, The Fourth International Congress on School Hygiene, „Journal of Educational Psychology" 1913, October, vol. 4, Issue 8, s. 476-478; Fourth International Congress on School Hygiene, Buffalo, New York USA, August 25-30, 1913. Transactions, Edited by Thomas A. Storey, Buffalo 1914, OPEN LBRARY 7064547 M.

${ }^{17}$ Przewodniczącym stałego komitetu grupy polskiej był reprezentujący Uniwersytet we Lwowie - profesor Kazimierz Twardowski, zaś jego zastępcą - dr Odo Bujwid z Uniwersytetu w Krakowie. Warto również wspomnieć obecność w gronie Polish Societes - L. Biera, M. Biehler, T. Janiszewskiego, E. Piaseckiego. Podano za: Fourth International..., s. 19, 27, 28, 64.

${ }^{18}$ A. Aleksandrowiczówna, Z. Benni, I. Moszczeńska-Rzepecka, S. Kalinowski, J. Opieński, A. Łukasiewicz, E. Szajewski, A. Szycówna, A. Wallek, L. Zarzecki, B. Żulińska. Podano za: Fourth International..., s. 64-65.

${ }^{19}$ S. K o p c z y ń s k i, Higiena szkolna..., s. 17.

${ }^{20}$ Por. B. S z c z e p a ń s k a, Wychowanie dla pokoju w publicystyce Polskiego Stowarzyszenia Przyjaciół Pokoju na łamach czasopisma "Ludzkość", [w:] Pokój jako przedmiot badań społecznych i pedagogicznych, red. W. L e ż a ń s k a, T. J a ł m u ż n a, Łódź 2006, s. 90-98.

${ }_{21}$ M. S., Krótkie wiadomości o higienie szkolnej za granica, ,Medycyna” [dalej: M] 1879, s. 285; B. W i c h e r k i e w i c z, Słów kilka o lecznicy szkolnej w Davos, Z 1888, s. 304; W. O t ł u s z e w s k i, Kilka słów o zakładach Paryża i Berlina dla dzieci z niedorozwojem psychicznym, M 1889, nr 19; W. R. K o z ł o w s k i, Kąpiele w Szwecji i kąpiele szkolne, „Przegląd Pedagogiczny” 1901, s. 68; Kąpiele szkolne w Niemczech, „Przegląd Pedagogiczny” 1901, s. 71; S. K o p c z y ń s k i, Urządzenia higieniczne we wzorowych szkołach w Szwajcarii i w Niemczech, Z 1902, s. 928; S. S te rling, Higiena w szkolnictwie szwajcarskim, „Nowe Tory” 1907, s. 45; P i o t r o w s k i, O instytucji lekarzy szkolnych za granicą, Z 1907, s. 194. 
Stosunkowo zbliżona liczna grupa artykułów prezentowała pracę dydaktyczno-wychowawczą w szkołach w różnych krajach europejskich i rozwiązania w nich stosowane, a mające na celu dbałość o zdrowie uczniów ${ }^{22}$.

\section{Rozwój zainteresowań zagranicznym dorobkiem w zakresie kultury zdrowotnej szkoły w polskim czasopiśmiennictwie medycznym w okresie dwudziestolecia międzywojennego}

Zainteresowanie zdrowotną kulturą szkoły w II Rzeczypospolitej Polskiej znalazło wyraz w publicystyce tego okresu. Czasopiśmiennictwo - szczególnie medyczne - niewystarczająco wydaje się dotąd eksplorowane, stanowi interesujące i bogate źródło do badania wpływów, które formowały koncepcję i model organizacyjny oraz praktykę higieny szkolnej, mających służyć idei „zdrowego narodu” lub „zdrowego społeczeństwa obywatelskiego”. Z pierwszą z wymienionych idei łączyły się poglądy Tomasza Janiszewskiego, który znaczenie zdrowia określił następująco: „[...] zdrowie fizyczne i moralne, zdrowie [...] które zapewnia przyszłość narodu, przyczynia się do stworzenia narodu o niskiej śmiertelności i chorobliwości, narodu silnego, odpornego, o silnych nerwach i silnej woli, a o skromnych wymaganiach, który we wzmożonym współzawodnictwie międzynarodowym mógłby nie tylko się utrzymać, ale rozwinąć w pełni wszystkie swoje zdolności i jak najwięcej przyczynić się do ogólnoludzkiego dorobku, dorzucić jak najwięcej oryginalnych pierwiastków ogólnoludzkich"23. Z ideą szkoły działającej na rzecz „zdrowego społeczeństwa” łączył się natomiast pogląd M. Kacprzaka: „Z chwilą, kiedy uczęszczanie do szkoły stało się obowiązkiem wszystkich warstw społecznych, szkoła musiała zmienić swój kierunek przechodząc z wyłącznego nauczania do wychowania i przygotowania obywateli do życia w pełnej zbiorowości społecznej. Higieniczne wychowanie winno tworzyć fundament tego przygotowania obywatelskiego"24.

${ }^{22}$ D u n i n-S u l g o s t o w s k a, Slöjd i jego stanowisko wobec wychowania i higieny, Z 1904, nr 9; J. J a worski, Znaczenie tzw. szkół leśnych, szkół na otwartym powietrzu, Z 1913, s. 57; B. K a c z o r o w s k i, Podział czasu i sposób życia dzieci w szkole na wolnym powietrzu w Charlotenburgu, „Przegląd Higieniczny” 1910, nr 8 i 9; S. K a r p o w i c z, Gry i ćwiczenia fizyczne w Niemczech, Szwajcarii i Krakowie, Z 1900, s. 323-326; J. K ra m s z t y k, W sprawie kolonii letnich i ogródków dziecięcych w Niemczech, Z 1900, s. 172; A. K r y s iń s k i, Wychowanie fizyczne w Szwecji, „Sprawy Szkolne” 1908, grudzień; K I i n k, Wychowanie fizyczne w szkołach angielskich, „Szkoła” 1913, s. 432; E. N e u m a rk o w a, O slöjdzie pedagogicznym, Z 1896, s. 275; W. O s t e r l o ff, Z powodu szkoły nowego typu w Abbotsholm, „Przegląd Pedagogiczny 1905, nr 1-2; E. P i a s e c k i, Szwedzki i niemiecki system gimnastyki wobec fizjologii i higieny, „Przegląd Lekarski” 1902, nr 140.

${ }^{23}$ T. J a n i s z e w s k i, Społeczne znaczenie zdrowia, M 1931, nr 15-16, s. 509.

24 Protokół z posiedzenia lekarzy szkolnych w dniu 21 XI 1929, Z 1930, nr 2, s. 89. 
Problematyką higieny szkolnej za granicą zajmowano się głównie na łamach czasopism ogólnolekarskich oraz higienicznych. Spośród czasopism lekarskich były to zwłaszcza periodyki o następujących tytułach: „Medycyna Doświadczalna i Społeczna”, „Nowiny Lekarskie”, „Lekarz Polski”, „Polska Gazeta Lekarska”, „Nowiny Społeczno-Lekarskie”, „Warszawskie Czasopismo Lekarskie”.

Natomiast grupę czasopism higienicznych, najczęściej prezentujących na swych łamach publikacje dotyczące zagranicznych koncepcji i praktyki „zdrowej szkoły” stanowiły: „Zdrowie” - „Zdrowie Publiczne”, „Higiena Ciała i Sport”, „Higiena Psychiczna".

Na łamach czasopiśmiennictwa medycznego okresu międzywojennego można odnaleźć liczne odwołania do polskich tradycji w dziedzinie kultury zdrowotnej szkoły. Najczęściej sięgano do dorobku Komisji Edukacji Narodowej, szczegółowo odnosząc się do jej „Ustaw” w zakresie edukacji fizycznej i zdrowotnej i podkreślając przy tym zasługi Stanisława Konarskiego i Grzegorza Piramowicza ${ }^{25}$. Powoływano się na sięgające XVI w. przykłady objęcia opieką medyczną studentów, jak i bliższe, XIX-wieczne osiągnięcia związane z ustanowieniem przez Tadeusza Czackiego lekarzy szkolnych w Liceum Krzemienieckim. Przywoływano i gruntownie analizowano koncepcje wychowania fizycznego Jędrzeja Śniadeckiego. Przedstawiano dorobek Polaków w zakresie higieny szkolnej w poszczególnych zaborach $^{26}$. Rodzime źródła inspiracji dla kultury zdrowotnej szkoły polskiej na łamach prasy są więc wyraźnie widoczne.

Na łamach polskich czasopism medycznych znaleźć można jednak znacznie więcej niż przed I wojną światową artykułów dotyczących zagranicznych koncepcji i praktycznych rozwiązań w zakresie optymalizacji pracy szkoły poprzez podniesienie jej kultury zdrowotnej.

Wiązać to można z bardziej ożywioną międzynarodową współpracą w dziedzinie zarówno zdrowia, jak i edukacji. Z jednej strony pojawienie się tych publikacji stanowiło wyraz kontynuacji wcześniej nawiązywanych przez Polaków kontaktów z międzynarodowym ruchem higienistów szkolnych, jak i pedagogów. Bogatszy wybór tych artykułów na łamach prasy polskiej wynikał z udziału przedstawicieli Polski w pracach międzynarodowych - tak dawniej działających, jak i nowo powstałych - organizacji, zwłaszcza Sekcji Higieny Ligi Narodów ${ }^{27}$, Międzynarodowego Urzędu ds. Higieny Publicznej28, Międzynarodowej Rady Pielę-

${ }^{25}$ S. K o p c z y ń s k i, Nadzór lekarski nad szkołami i ruch higieniczno-szkolny w Polsce, „Wychowanie Fizyczne" 1920, nr 3-4, s. 39-66; nr 56, s. 119-129. Por. Z przepisów Komisji Edukacji Narodowej (w 150 rocznicę), „Wychowanie Fizyczne” 1923, nr 9-12, s. 127-129.

${ }^{26}$ Tamże; A. W r z o s e k, Jędrzeja Śniadeckiego działalność naukowa, lekarska i pedagogiczna, M 1938, nr 13, s. 505-512; L. Z e m b r z u s k i, Jędrzej Śniadecki 1768-1838. Życie i działalność, tamże, nr 13, s. 500-505.

${ }^{27}$ K. Ty s z k a, Organizacja Higieny Ligi Narodów, „Polska Gazeta Lekarska” 1924, nr 46, s. 709-710; S. T u b i a s z, Wymiany urzędników sanitarnych urządzane przez Sekcję Higieny Ligi Narodów, „Warszawskie Czasopismo Lekarskie” 1924, nr 5, s. 197-198.

${ }^{28}$ Udział Polski w pracach międzynarodowych Instytucji Higieny Publicznej, „Polska Gazeta Lekarska” 1929, nr 29-30, s. 567. Zob. też: J. P o l a k, W sprawie organizacji międzynarodowej higieny publicznej, Z 1923, nr 7-9; W. C h o d ź k o, Aktualne sprawy sanitarne na terenie międzynarodowym 
gniarek, Międzynarodowego Związku Przeciwgruźliczego, Międzynarodowego Stowarzyszenia Opieki nad Dzieckiem, Stowarzyszenia Szkół na Wolnym Powietrzu, Sekcji Zdrowia Światowej Federacji Towarzystw Wychowania, Zrzeszenia Nowego Wychowania. Do udziału w międzynarodowych zjazdach, kongresach, konferencjach, wystawach delegowały Polaków także władze odrodzonego po latach niewoli państwa lub organizacje społeczne - Ministerstwo Wyznań Religijnych i Oświecenia Publicznego, Departament Służby Zdrowia Ministerstwa Spraw Wewnętrznych czy Polski Związek Przeciwgruźliczy.

Dużą rolę odgrywały także Fundacja Johna Rockefellera, Amerykański Czerwony Krzyż, Amerykański Komitet Pomocy Dzieciom przekształcony w Polsko-Amerykański Komitet Pomocy Dzieciom. Wśród najbardziej aktywnych we współpracy międzynarodowej postaci należałoby wymienić: S. Kopczyńskiego, Witolda Chodźko, Marcina Kacprzaka, Karola Mitkiewicza, Eugeniusza Piaseckiego, Kazimierza Dąbrowskiego.

W pewnej mierze ten transfer zagranicznych rozwiązań poprzez publikacje prasowe był efektem wzmożonych prywatnych wyjazdów lekarzy.

Pośrednia łączność ze światowym ruchem na rzecz „zdrowej szkoły” znajdowała odbicie $w$ licznych recenzjach, streszczeniach i przeglądach piśmiennictwa zagranicznego ${ }^{29}$. Przy czym należy zauważyć, że obok znaczących pozycji światowych, o których pisano na łamach polskich czasopism, pojawiały się także informacje o obecności na łamach prasy zagranicznej polskiego dorobku w tym zakresie, docenianego na forum międzynarodowym ${ }^{30}$.

Można wyróżnić następujące obszary tematyczne dotyczące kultury zdrowotnej szkoły w grupie publikacji odnoszących się do zagranicznego dorobku w tym zakresie, pojawiających się na łamach czasopism medycznych II Rzeczypospolitej Polskiej:

- budynki szkolne, ich wyposażenie i otoczenie;

- stan zdrowia uczniów i opieka lekarsko-higieniczna nad nim;

- oddziaływania edukacyjne szkoły na rzecz utrzymania i wzmacniania zdrowia indywidualnego i społecznego - metody, środki i realizatorzy;

\footnotetext{
i w Polsce, „Medycyna Doświadczalna i Społeczna” 1923, nr 7-9.

${ }^{29}$ Obfitość prezentowanych na łamach prasy medycznej recenzji i streszczeń prac zagranicznych - zwłaszcza niemieckich, francuskich, włoskich, angielskich, austriackich, amerykańskich sprawia, że szczegółowa analiza tych pozycji mogłaby się stać przedmiotem odrębnych rozważań. Por. Dr K o c h, Przyśpieszenie wzrostu powojennej młodzieży niemieckiej, Archiv für Soziale Hygiene und Demographie, 1933/34, z. 6, Z 1934, nr 11, s. 1008; K. N u s s e I, Wskazania do stosowania ćwiczeń cielesnych u dzieci gruźliczych, München. Med. Woch. 1925/18, Z 1926, nr 3, s. 164-165; Dr L. G e r o t, Rola pielęgniarki szkolnej, Le Médicine Scolaire, t. XVII/4, 198, Z 1929 nr 6; II Surmenage nelle Scuole, La Medicina del Lavoro 1932/1, „Nowiny Społeczno-Lekarskie” 1933, nr 9, s. 132; L. P a r k e r, 50-lecie Królewskiego Instytutu Sanitarnego w Anglii 1876-1926, „Journal of the Royal Sanitary Institute", July 1926, Z 1926, nr 3, s. 502-505; Kronika, Dr H. K e Il e r, Postępy w dziedzinie higieny szkolnej w Wiedniu, Volksgesundheit 1929, 1-2, Z 1929, nr 2, s. 121-122; J. O. M u r r a y, Public Health, Odżywianie i nastrój umysłu, „Public Health”, Z 1934, nr 11, s. 1008.

${ }^{30}$ Do czasopism zagranicznych szczególnie często prezentujących osiągnięcia polskie $\mathrm{w}$ dziedzinie higieny szkolnej należało francuskie „Le Médicine Scolaire”, a poza nim także norweskie - „Vor Scole”, „Nordisk Kvinogimnastik”, angielskie „The New Era”.
} 
- program nauczania a „przeciążenie” uczniów;

- innowacyjne rozwiązania organizacyjne - „szkoły na otwartym powietrzu”, „szkoły leśne”, „osiedla szkolne”;

- klimat psychospołeczny szkoły.

W pierwszej z wymienionych grup tematycznych na szczególną uwagę zasługuje artykuł S. Kopczyńskiego stanowiący sprawozdanie z delegacji do Anglii, Belgii i Holandii. Podróż tę odbył ówczesny naczelnik Wydziału Higieny Szkolnej i Wychowania Fizycznego z ramienia Sekcji Higieny Ligi Narodów przy wsparciu Fundacji J. Rockefellera, oddelegowany przez Ministerstwo Wyznań Religijnych i Oświecenia Publicznego. Wspominał on, iż „[...] pod wieloma względami wizytowane przez naszą delegację urządzenia higieniczno-szkolne służyć mogą za wzór do naśladowania"31.

S. Kopczyński przedstawił szczegółowo angielskie budynki szkolne, podkreślając dostrzeżone dobre wietrzenie sal lekcyjnych. Również otoczenie tych budynków - boiska, a także wyposażenie - natryski, baseny, bardzo czyste ustępy, jednoosobowe ławki, szatnie, urządzenia do mycia rąk, solidne dębowe podłogi, ściany wyłożone majoliką - wzbudzały podziw wizytującego. Jeszcze bardziej podobały się S. Kopczyńskiemu szkoły belgijskie i holenderskie, w których dostrzegł „dużo światła i powietrza”. Poza tym sprawozdawca w szkołach tych krajów akcentował: idealną czystość i dostępność ustępów szkolnych, łatwe w utrzymaniu czystości - zmywalne - powierzchnie ścian i podłóg, obecność basenów i urządzeń natryskowych wykończonych majoliką, a w salach lekcyjnych - „tryptyki” - tablice o powiększonej powierzchni do pisania. Poza higienicznym, wysokim standardem zwiedzanych budynków i ich funkcjonalnością, S. Kopczyński podkreślał ich estetykę, spostrzegając: „Czyste, praktyczne budynki szkolne w Holandii jednocześnie uderzają swoją prostotą"32.

Recenzujący artykuł S. Kopczyńskiego - Tadeusz Jaroszyński podkreślał, iż to szczegółowe przedstawienie urządzeń szkolnych w Anglii, Belgii i Holandii, które stanowić mogą wzór do naśladowania, powinno przyczynić się do poprawy sytuacji w tym zakresie w Polsce ${ }^{33}$.

Inny recenzent spuentował sprawozdanie S. Kopczyńskiego następująco: „Porównanie z Polską, niestety jaskrawo odbijającą od szablonów opisanych, zwiększa praktyczne znaczenie lektury"34.

Podobnie, budownictwu szkolnemu i jego urządzeniom oraz otoczeniu, wiele miejsca w swoim obszernym sprawozdaniu poświęcił dr Karol Mitkiewicz ${ }^{35}$. Na

31 S. Ko p c z yńs ki, Higiena szkolna i wychowanie fizyczne na Zachodzie. Sprawozdanie z delegacji higieniczno-szkolnej do Anglii, Belgii i Holandii od dnia 20.03-9.05.1924, „Medycyna Doświadczalna i Społeczna" 1926, z. 1-2, t. VI, s. 142-143.

32 Tamże, s. 121.

${ }^{33}$ T. J a ros z y ń s ki, Recenzja pracy dr. S. Kopczyńskiego „Higiena szkolna i wychowanie fizyczne na Zachodzie”, „Medycyna Doświadczalna i Społeczna”, Warszawa 1926, „Przegląd Pedagogiczny" 1926, nr 34.

34 Przegląd bibliograficzny: S. K o p c z y ń s k i, Higiena szkolna i wychowanie fizyczne na Zachodzie, Z 1926, nr 11, s. 605-606.

35 Międzynarodowa Wystawa Higieniczna w Dreźnie, „Lekarz Polski” 1930, nr 2, s. 36. Por. Z po- 
uczestniczącym w II Międzynarodowej Wystawie Higienicznej w Dreźnie wizytatorze higieny szkolnej w Kuratorium Okręgu Szkolnego Warszawskiego szczególne wrażenie zrobił budynek szkolny stanowiący „ideał budownictwa szkolnego przyszłości". Był to płaski budynek o rozszerzonej - przez połączenie z werandą, ogródkiem i boiskiem - powierzchni. Użyte do jego budowy materiały - drewno, torf i szkło - sprawiały wrażenie lekkości, a usytuowane we wszystkich czterech ścianach okna - dawały niezwykle dużo światła, słońca, powietrza. Ponadto, wszystkie ściany tego budynku można było otwierać, a weranda tworzyła pomost, łączący salę szkolną z ogródkiem i dalej - z boiskiem. W trudnej sytuacji w dziedzinie budownictwa szkolnego w Polsce ten projekt mógł pobudzać władze ministerialne do refleksji.

Z kolei, kwestie sprzętu szkolnego, od którego rozpoczęła się intensyfikacja zainteresowania problematyką kultury zdrowotnej na łamach polskiego czasopiśmiennictwa jeszcze w czasach zaborowych - chodzi o ławki - podjęto w artykule ortopedów: dr Dezyderiusza i Wandy Oroszów. Asystenci Uniwersyteckiej Kliniki Dziecięcej w Pecs zwracali uwagę na trwające od ponad trzydziestu lat usiłowania, by stworzyć „idealną ławkę szkolną”, wskazując, że trudności w tym względzie wynikały z dyscyplinującego charakteru tego sprzętu. Przytaczali zdanie A. Baginsky'ego, iż „ławka szkolna jest jedynie środkiem pomocniczym nieudoskonalonych metod pedagogicznych”, a także inne postulaty, by „dopasować ławki do dzieci, a nie odwrotnie" oraz by dzieci zmieniały swoje miejsca w szkole w ciągu roku szkolnego z uwagi na pożądane, zmienne usytuowanie źródła światła. Autorzy artykułu przedstawili jako modelową sytuację w szkołach wiedeńskich, gdzie niektórym dzieciom z przyczyn ortopedycznych pozwala się brać udział w nauce szkolnej w pozycji leżącej na brzuchu. Reasumując swoje rozważania, stwierdzili, iż najlepsze rozwiązanie stanowi używanie nie ławek, ale stołów i krzeseł, które mają zalety zarówno z punktu widzenia pedagogów, jak i lekarzy. Sprzęty te mogą być rozmaitej wielkości, lekkie, by dzieci mogły je same przenosić. Najbardziej polecany przez ortopedów model stołu posiadał przesuwaną, ruchoma płytę, która umożliwiała używanie pulpitu również w pozycji stojącej, a ponadto był łatwy do utrzymania w czystości, gdyż nie miał zakamarków i szczelin, w których mógłby gromadzić się kurz ${ }^{36}$.

Stan zdrowia uczniów, a dokładniej jego badanie oraz działania wzmacniające zagrożone zdrowie i zabiegi profilaktyczne, a także powiązaną z tymi zagadnieniami kwestię opieki lekarsko-higienicznej „dla dziatwy szkolnej” podejmowano w dość licznych artykułach.

Poza przedstawionymi już wcześniej sprawozdaniami S. Kopczyńskiego z jego podróży do Europy Zachodniej i K. Mitkiewicza z II Międzynarodowej Wy-

siedzenia lekarzy szkolnych w MWRiOP, posiedzenie w dniu 18 IX 1930 r., „Wychowanie Fizyczne” 1931, nr 1, s. 30-32.

${ }^{36}$ D. i W. Oroszowie, Wychowanie fizyczne pod hasłem udoskonalenia ortopedycznego, „Polska Gazeta Lekarska” 1931, nr 42, s. 815. Autorzy artykułu wskazywali bardzo konkrety model sprzętu hannoverskiej fabryki Niederkrom, który najlepiej spełniał ich wymagania. 
stawy Higienicznej w Dreźnie, wątki takie zawierają artykuły dotyczące Francji ${ }^{37}$, Norwegiii ${ }^{38}$, Angliii ${ }^{39}$, Niemiec ${ }^{40}$, Szwajcarii41, Stanów Zjednoczonych ${ }^{42}$ i Japonii ${ }^{43}$.

Dominowały w tych publikacjach sprawy walki z gruźlicą i zapobiegania tej chorobie ${ }^{44}$. Pojawiały się kwestie stosowania szczepień ochronnych, zwłaszcza przeciwgruźliczych ${ }^{45}$, przeciwbłoniczych i przeciwdyfterytowych ${ }^{46}$ oraz zachorowalności na te choroby ${ }^{47}$. Zajmowano się także metodyką badań lekarskich i organizacją zarówno lekarskiej, jak i pielęgniarskiej opieki nad zdrowiem dzieci w wieku szkolnym ${ }^{48}$.

Antoni Nowiński - praktykujący w Bydgoszczy lekarz - powoływał się na rozwiązania stosowane w USA i w Niemczech, gdzie dużo mniejszą niż w Polsce wagę przywiązywano do stałej opieki lekarsko-higienicznej w szkołach średnich, a mocniej dbano o objęcie taką opieką uczniów szkół powszechnych, gdyż uznawano, iż to typ szkoły „[...] przez który powinien przechodzić cały naród, więc ma ona pierwszorzędne znaczenie państwowe"49.

Z kolei płk dr Jan Babecki, krytycznie odnosząc się do opieki lekarskiej nad zdrowiem uczniów w polskich szkołach powszechnych, przywoływał poglądy amerykańskiego higienisty Miltona J. Rosenaua: „[...] wprowadzenie w życie przymusu powszechnego nauczania bez równoczesnego zapewnienia dzieciom w szkole odpowiednich warunków higienicznych nauczania, dobrej wody, czyste-

${ }^{37}$ L. D u f e s a t e I, Stan obecny nad szkołami we Francji i zagranica, Z 1927, nr 2, s. 93-98; t e n ż e, Wszawica w szkole powszechnej, Z 1927, nr 2, s. 153; Dr L e g r o u x, O ośrodkach higieny szkolnej, Z 1927, nr 2, s. 132-135.

${ }^{38} \mathrm{~S}$. R u d z k i, Walka z gruźlicą wśród dziatwy i młodzieży w Norwegii, „Polska Gazeta Lekarska" 1931, nr 3, s. 614-615.

${ }^{39}$ M. Kacprzak, Z zagadnień sanitarnych Anglii, „Warszawskie Czasopismo Lekarskie” 1925, nr 10, s. 447-449; Zdrowie dzieci szkolnych w Anglii, „Nowiny Społeczno-Lekarskie” 1933, nr 18, s. 226-227; M. L., Zdrowie dziecka szkolnego w Anglii, „Nowiny Społeczno-Lekarskie” 1936, nr 17, s. 244.

${ }^{40}$ Sprawozdania: J. F r i t z, 36 Kongres Pediatrów Niemieckich, „Higiena Ciała i Sport” 1925, nr 5, s. 39; Lekarze szkolni w Prusach, „Orędownik Zdrowia” 1927, nr 11, s. 60.

${ }^{41} \mathrm{I}$. K o r s a k, Aktualne zagadnienia higieny szkolnej w Polsce - w zestawieniu ze Szwajcarią, „Lekarz Polski” 1939, nr 4, s. 82-87.

${ }^{42}$ M. K a c p r z a k, Sprawy sanitarne w Stanach Zjednoczonych, „Medycyna Doświadczalna i Społeczna", 1925, t. IV, z. 3-4, s. 332-371.

${ }^{43}$ Wiadomości bieżące, Poradnie dla dzieci i higienistki szkolne w Japonii, Z 1924, nr 2, s. 80.

${ }^{44}$ S. R u dzk i, Walka z gruźlicą..., Protokół z posiedzenia lekarzy szkolnych z 20 XI 1930, „Polska Gazeta Lekarska” 1931, nr 3, s. 59. Zob. też: Dział sprawozdawczy, L. R e g mu n t-S obi e s z czań s ki, Wrażenia z Kongresu Międzynarodowego Stowarzyszenia Opieki nad dzieckiem w Liége, Z 1930, nr 17, s. 830; Wiadomości bieżące, Dziewiąty Międzynarodowy Kongres Opieki nad Dzieckiem w Leodium, „Polska Gazeta Lekarska” 1931, nr 8, s. 156.

${ }^{45}$ S. R u d z ki, Szczepienia przeciwgruźlicze a wiek szkolny, Protokół z posiedzenia lekarzy szkolnych w MWRiOP z dn. 31.09.1933 r., Z 1934, nr 1, s. 80-81.

${ }^{46}$ P. V i g n e, R. C r e m i e u, W sprawie profilaktyki szkolnej krztuśca i błonicy, „L'Avenir Medical” 1926, nr 8, rec. dr Z. S wi d e r, „Zdrowie” 1927, nr 1, s. 46-48.

47 Szkarlatyna w Anglii i Walii, „Nowiny Społeczno-Lekarskie” 1933, nr 18, s. 227.

${ }^{48}$ Badanie lekarskie dzieci angielskich w wieku szkolnym, „Nowiny Społeczno-Lekarskie” 1933, nr 19, s. 242; M. B a b i c ka, Sprawozdanie ze Zjazdu Pielęgniarskiego w Rzymie, „Polska Gazeta Lekarska" 1929, nr 33-34, s. 624-626.

${ }^{49}$ A. N o w i ń s k i, Podstawowe zasady higieny szkolnej, „Nowiny Lekarskie” 1926, z. 7, s. 260. 
go powietrza i odpowiednich pomieszczeń szkolnych jest zgoła przestępstwem administracji kraju wobec narodu"50.

W latach trzydziestych wraz z narastaniem skutków kryzysu gospodarczego, przekładającego się na „kryzys szkolny” wzmagała się już wcześniej rozpoczęta dyskusja na temat organizacji opieki lekarsko-higienicznej w polskiej szkole ${ }^{51}$. Krytykowano coraz mocniej i wyraźniej nadmiernie rozbudowaną opiekę w szkołach średnich, przy jej niedostatecznym stanie w szkołach powszechnych ${ }^{52}$. Dyskusja ta wychodząca od modelu szkolnej opieki lekarskiej przeradzała się w spór nad polskim systemem szkolnym w ogóle, systemem dualistycznym, gdzie niedowartościowanie i deprecjacja szkoły powszechnej wyrażała się w braku dbałości o zdrowie uczęszczających do niej dzieci.

Argumentów za modyfikacją wypracowanego i zastosowanego przez S. Kopczyńskiego modelu opieki higieniczno-lekarskiej poszukiwano w doświadczeniach zagranicznych. Feliks Wasilewski pisał: „W szkołach średnich opieka lekarsko-higieniczna powinna być uważana za luksus, na który mogą sobie pozwolić narody bogate. Wiele stanów Ameryki Północnej pomimo względnego dobrobytu nie ma dotychczas zorganizowanej opieki higieniczno-lekarskiej w szkołach średnich, natomiast cała akcja profilaktyczna skupiona jest na szkole powszechnej, gdyż: tu - trafia każde dziecko, tu - trafia dziecko najmłodsze, którego organizm jest najmniej odporny, tu - przebywa dziecko najdłużej i najbardziej potrzebuje opieki lekarskiej" ${ }^{3}$.

Z kolei Witold Chodźko - były Minister Zdrowia Publicznego, współpracujący z Międzynarodowym Urzędem Higieny Publicznej i związany z Państwową Szkołą Higieny w Warszawie - przytaczał stwierdzenie Schwéersa, dyrektora oddziału higieny społecznej w Głównym Urzędzie Zdrowia m. Berlina: „Uczęszczanie do szkoły jest obowiązkiem ustawowym (przymus szkolny). Już z tego tylko powodu, ale również $w$ interesie publicznej ochrony zdrowia - jest więc niezbędne takie ukształtowanie szkolnictwa, ażeby można było uniknąć w granicach możliwości szkód z nim związanych i ażeby uczęszczanie do szkoły przyniosło młodzieży szkolnej korzyści również dla jej stanu zdrowia"54.

50 J. B a b e c k i, Opieka lekarska w szkole, „Warszawskie Czasopismo Lekarskie” 1929, nr 3, s. 70. M. J. Rosenau był profesorem Wydziału Medycyny Zapobiegawczej Uniwersytetu Harvarda, przekształconego w 1922 r. w Harvardzką Szkołę Zdrowia Publicznego i autorem m.in. wydanej w roku 1913 pracy pt. Medycyna zapobiegawcza. Podano za: www.cdc.gov/MMMWR,CDC, 15 Oct.19999/48(40), USA. gov. Departament of Health and Human Sciences. Zob. też: M. J. R o s e n a u, G. H. W h i p ple, J. W. Tr a s k, T. W. S a I o m o n, Preventive medicine and hygiene, New York, Appleton 1923.

51 Por. J. B a b e c k i, Opieka lekarska w szkole; J. Z e y la n d, W sprawie organizacji opieki lekarskiej nad dziećmi szkolnymi, „Nowiny Lekarskie” 1933, z. 5, s. 148-149.

52 W. C h o dź k o, Polski lekarz powiatowy, „Zdrowie Publiczne” 1935, nr 9; W. G ą d z i k i e w i c z, Organizacja nadzoru nad szkołami powszechnymi i rola lekarza powiatowego w tym nadzorze, „Nowiny Społeczno-Lekarskie” 1936, nr 1-2. Por. W. G ą d z i k i e w i c z, Uwagi w sprawie organizacji opieki higieniczno-lekarskiej w szkołach polskich, „Wychowanie Fizyczne” 1934, nr 3-4; t e n ż e, Projekt organizacji opieki higieniczno-lekarskiej w szkołach powszechnych, „Wychowanie Fizyczne” 1935 , $\mathrm{nr} 11-12$.

${ }^{53}$ F. W a s i l e w s k i, O opiece higieniczno-lekarskiej na terenie szkół powszechnych, Z 1931, nr 20, s. 1138-1139.

54 W. C h o d ź k o, Polski lekarz powiatowy a higiena szkolna, „Lekarz Polski” 1939, nr 2, s. 26. 
Wielką odpowiedzialność państwa za zdrowie uczniów - właśnie szkół powszechnych - podkreślano, odwołując się do koncepcji amerykańskiego higienisty M. J. Rosenaua i powołując się na praktykę sądową w Niemczech ${ }^{55}$.

Natomiast uracjonalnienie opieki higieniczno-lekarskiej nad dziećmi i młodzieżą w wieku szkolnym i podniesienie autorytetu lekarza szkolnego w oparciu o doświadczenia szwajcarskie proponowała Idalia Korsak. Na posiedzeniu Klubu Lekarzy Polskich zrelacjonowała ona swą podróż do Szwajcarii. Przedstawiła gruntowną analizę tamtejszych rozwiązań w zakresie kultury zdrowotnej szkoły. Szczególną przydatność w Polsce wzorów stosowanych w wielu kantonach szwajcarskich widziała referentka w szkołach wiejskich ${ }^{56}$.

Kolejną grupę zagadnień na łamach polskiego czasopisma medycznego w II RP - wątki dotyczące oddziaływań szkoły na rzecz edukacji zdrowotnej znaleźć można w artykułach przedstawiających rozwiązania stosowane w krajach europejskich ${ }^{57}$, jak również - szczególnie wiele - odnoszących się do Stanów Zjednoczonych ${ }^{58}$.

„Propaganda higieny przez szkołę” uznawana przez Marcina Kacprzaka za najmłodszy, ale niewątpliwie najważniejszy dział higieny szkolnej, w konfrontacji z zagranicznymi doświadczeniami wypadała w Polsce niekorzystnie, nie doceniano jej znaczenia. Wyraźny wówczas w Polsce nacisk na nauczanie higieny, zdaniem M. Kacprzaka - redaktora czasopisma „Zdrowie”, związanego z Państwową Szkołą Higieny w Warszawie - był błędny. Tę obserwowaną w Polsce tendencję wypierało na świecie inne nastawienie, wyżej wartościujące praktyczne oddziaływania, za których istotę uznawał on „[...] wpajanie w ucznia pewnych nawyknień higienicznych i wdrażanie do pielęgnowania własnego zdrowia poprzez automatyzm czynności, które mają stać się drugą naturą"59.

Stąd też dużą wartość aplikacyjną miały prezentowane doświadczenia zagraniczne. W relacji z Włoch M. Kacprzak akcentował: „Przełomową, godną ze wszech miar naśladowania stroną nowego programu nauczania higieny jest to, że nauczanie rozpoczyna się od rzeczy praktycznych: od mycia rąk, twarzy, czyszczenia paznokci, a nie od anatomii... Gry, historyjki, bajki, dostępne opowiadania, obrazki mają służyć za główną metodę nauczania. Czystość ma być stawiana na równi z mądrością i postępami w nauce, a wizytatorowie szkół mają zawsze odnotowywać, w jakim stanie są dzieci pod względem czystości i czy nauczyciel umiał zaszczepić im niezbędne zasady higieny życia codziennego"60.

55 Odpowiedzialność państwa pruskiego za zakażenie gruźlicą w szkole przez nauczyciela, „Lekarz Polski” 1936, nr 9, s. 134 na podstawie „Münch. Med. Woch.” 1936/22.

56 I. Ko r s a k, Aktualne zagadnienia...

57 M. K a c p r z a k, Wrażenia z Mediolanu, „Warszawskie Czasopismo Lekarskie” 1925, nr 12, s. 522-524; t e n ż e, Z zagadnień sanitarnych...; t e n ż e, Propaganda higieny przez szkołę, Z 1929, nr 11, s. 696-702.

${ }^{58}$ Te n ż e, Sprawy sanitarne...; S. S z u m a n, Propaganda higieny w szkołach amerykańskich, „Higiena Ciała i Sport” 1926, nr 9, s. 3-7; Recenzje: J. P o l a k - Rene Sand, Nauczanie powszechne w dziedzinie higieny, Revue d'hygiene et de médecine preventive, X 1927, Z 1927, nr 12, s. 808-813; M. K a c p r z a k, Mleko w Stanach Zjednoczonych, „Orędownik Zdrowia” 1929, nr 1, s. 10-11; Lekarze amerykańscy o metodach propagandy higieny, „Lekarz Polski” 1930, nr 2, s. 36.

${ }_{59}$ M. K a c p r z a k, Propaganda higieny..., s. 696.

60 Tamże, s. 701-702. 
Przeniesienie odpowiedzialności za promowanie zdrowia wśród uczniów w szkole z lekarza, co było raczej tendencją dominującą w Polsce, na nauczyciela i ewentualnie także higienistkę szkolną, M. Kacprzak dostrzegał jako obowiązujące zarówno we Włoszech, jak i w USA. W krajach tych większa rola nauczyciela w propagowaniu zdrowia uzasadniana była tym, iż nauczyciel miał codzienny kontakt z dzieckiem, stosował zasady higieny sam, by rzeczywistość nie zaprzeczała zasadom higieny - przez co łatwiejsze wydawało się szerzenie zasad higieny wśród rodziny i otoczenia społecznego szkoły.

Rodowód ruchu popularyzującego higienę w USA zarówno przez M. Kacprza$k^{61}$, jak i przez René Sand ${ }^{62}$ wywodzony był z niezwykłej aktywności Ministerstwa Rolnictwa, które przy współudziale farmerów i przedsiębiorców zajmujących się obrotem produktami spożywczymi przyczyniło się do rozwoju metod, form i środków popularyzacji produktów, przede wszystkim stanowiących narzędzie marketingowe. Połączenie promowania zdrowia za pomocą zdrowego produktu, przy oczekiwaniu wzrostu dochodów producentów i handlowców przedstawił M. Kacprzak na przykładzie „mlecznej akcji propagandowej”. Fundusz tej akcji, nieograniczonej zresztą do szkół, składał się z płaconych od sprzedanych lub kupionych każdych stu litrów mleka po zaledwie 1 cencie. Choć w czasie organizowanych degustacji z pogadankami, wykładów i odczytów o zdrowiu, przedstawień scenicznych, w broszurach, plakatach i ogłoszeniach nie zachęcano wprost do kupowania mleka, to w rezultacie wszystkich tych działań - jak twierdził M. Kacprzak „[...] obywatel nie może nie przyjść do przekonania, że mleko dla jego zdrowia jest prawie tak niezbędne jak powietrze"63.

Jednak zdaniem R. Sand narodową specyfikę i odrębności mentalności obywateli różnych państw trzeba szanować i nie „amerykanizować”, a poza tym „[...] w obrazkach i filmach uwzględniać nawyknienia i obyczaje ludowe, w odczytach [...] poziom przygotowania i psychikę narodową"64.

Daleki od takiego umiaru i powściągliwości jest autor kolejnego artykułu, w którym fascynacja szczególnie atrakcyjnością metod, form, a zwłaszcza środków amerykańskiej edukacji zdrowotnej jest uderzająca.

Stefan Szuman - wizytator higieny szkolnej w Kuratorium Poznańskiego Okręgu Szkolnego podkreślał przywiązywanie w Stanach Zjednoczonych szczególnego znaczenia do realnych i praktycznych zadań higieny w szkole, określając jej sens następująco: „[...] jest ona przede wszystkim profilaktyką, ma uchronić ucznia przed chorobą, odkryć zawczasu niebezpieczeństwa grożące jego zdrowiu i zapobiec rozwinięciu choroby. Ma ze szkoły usuwać wszystko to, co działa szkodliwie na zdrowie młodego pokolenia, a natomiast popierać i potęgować te momenty wychowawcze, które rozwijają tężyznę fizyczną i odporność organizmu"65.

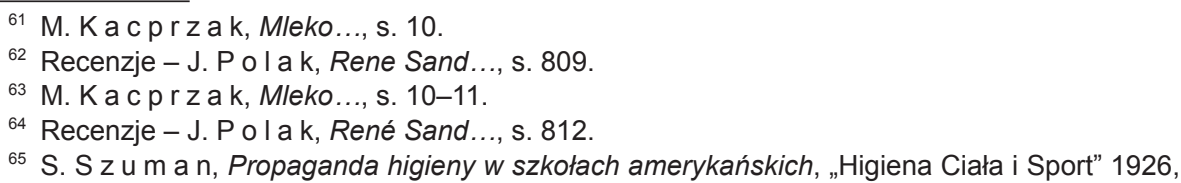
nr 9 , s. 3 . 
Autor artykułu dokonał konfrontacji stosowanych na gruncie polskim i amerykańskim metod, form i środków w nauce o zdrowiu na terenie szkoły. Dostrzegł, iż w amerykańskiej szkole stosowany był dużo bogatszy repertuar atrakcyjnych środków w postaci plakatów i broszur o treści higienicznej. Ów plakat higieniczny, mający skutecznie oddziaływać na ucznia spełniał wymagania zarówno dydaktyczno-wychowawcze, jak i artystyczne, gdyż był „[...] artystycznie wykonany [...] ożywiał monotonne ściany i działał swą treścią na wpatrującego się weń ucznia", zaś specyficzne cechy plakatu, który nie był z założenia poglądową tablicą do nauki higieny sprawiały, że miał on „[...] przyciągać wzrok dziecka i interesować swą barwą, budzić jego humor i działać treścią na jego ciekawość - streszcza się to w określeniach: wesoły, ładny, zabawny i ciekawy"66. Obok plakatów innymi również atrakcyjnymi dla uczniów środkami w nauczaniu higieny, stosowanymi w amerykańskich szkołach były bogato ilustrowane i zabawne broszury, zawierające bajki lub piosenki ${ }^{67}$. Wykorzystywano różne formy współzawodnictwa, często organizując konkursy, np. „mistrzów w jedzeniu warzyw” lub „mistrzów wagi proporcjonalnej do wzrostu"68.

Główny nacisk w amerykańskim wychowaniu higienicznym został położony, według S. Szumana, na wyrabianie dobrych przyzwyczajeń higienicznych, a nie tak, jak to odbierał w Polsce - na podawanie wiadomości. Ważne było przede wszystkim dla amerykańskiej szkoły, aby uczeń potrafił zastosować wiadomości z zakresu higieny we własnym, indywidualnym życiu i w życiu społecznym. Nie oznaczało to jednak zupełnej rezygnacji z powtarzania ujętych w reguły „dobrych zwyczajów higienicznych", uzupełnianych przez odpowiednią lekturę, ożywionych przez „wesoły, urozmaicony sposób podawania tych nauk uczniom”, popartych własnym przykładem nauczyciela i sugestiami lekarza, że stosowanie tych reguł higienicznych pozwala być „zdrowym i szczęśliwym”69.

S. Szuman dostrzegł też ciekawy pomysł połączenia wiedzy etnograficznej z higieniczną poprzez prezentowanie uczniom zwyczajów higienicznych w różnych kręgach kulturowych (Eskimosi, Azjaci, Arabowie). Podkreślał przywiązywanie ogromnej wagi do różnicowania stosowanych w nauce o zdrowiu metod i środków - w zależności od wieku uczniów. Dla starszych uczniów proponowany był udział w „Klubach Zdrowia”, lektura, pogłębianie wiadomości przez naukę somatologii i higieny społecznej, dbałość o wygląd sal szkolnych, troska o chorych oraz niezamożnych kolegów i koleżanki, a także zachęcanie innych do stosowania „dobrych obyczajów higienicznych”. Znamienną cechę nauki o zdrowiu w amery-

66 Tamże.

67 Tamże, s. 4. S. Szuman przytacza treść jednej z takich piosenek: „Co dzień ze smakiem mleko pije Stasio. Za nic nie przełknę - odpowiada Jasio. Staś zdrowy, tęgi wyrasta na zucha. Jaś został mały i chudy - jak mucha".

68 Tamże, s. 5.

69 Tamże, s. 4. Te reguły zostały ujęte w następujące: „Ośm prawideł zdrowia”: 1. Kąp się raz w tygodniu. 2. Zęby czyść min. raz dziennie. 3. Śpij jak najdłużej - przy otwartym oknie. 4. Pij tyle mleka, ile możesz, ale nie pij herbaty ani kawy. 5. Co dzień jedz trochę owoców i warzyw. 6. Pij min. trzy szklanki wody każdego dnia. 7. Ćwicz każdego dnia. 8. Dbaj o codzienne wypróżnienie. 
kańskiej szkole wyrażały, według S. Szumana, słowa umieszczane we wszystkich wydawnictwach higienicznych przeznaczonych dla uczniów, tj.: „Zdrowie, siła, radość dla wszystkich dzieci, wszystkich amerykańskich szkół"70.

Podkreślając praktyczny walor stosowanych w amerykańskich szkołach metod i środków wychowania higienicznego, autor artykułu sformułował postulaty, mogące poprawić niepokojący, jego zdaniem, stan w tej dziedzinie w Polsce. Należałoby przede wszystkim lepiej przygotować polskich nauczycieli do prozdrowotnej pracy w szkołach. Trzeba ponadto sformułować jasny, pełny, różnorodny i atrakcyjny dla uczniów program nauki o zdrowiu, a ponadto uzupełnić braki - tak ilościowe, jak i jakościowe - w środkach propagowania zdrowia oraz kontynuować dającą taką szansę, rozpoczętą już dzięki Polsko-Amerykańskiemu Komitetowi Pomocy Dzieciom współpracę z Amerykańskim Czerwonym Krzyżem ${ }^{71}$.

Społeczny walor propagowania w amerykańskich szkołach praktycznych zasad zachowania zdrowia, dzięki któremu wychowuje się „obywatela kulturalnego, uświadomionego higienicznie i znającego indywidualną i społeczną wartość zdrowia"72 podkreśla w swojej relacji z podroży po Stanach Zjednoczonych również M. Kacprzak ${ }^{73}$. Wskazuje on na ogromną rolę, jaką w uspołecznieniu higieny odgrywały stowarzyszenia promujące zdrowie i przedstawia działalność jednego z najbardziej znanych - „Związku Rycerzy Krzyżowych Zdrowia”. Podobnie jak S. Szuman, M. Kacprzak uznawał poglądowe metody, różnorodność atrakcyjnych środków i ich dostosowanie do wieku uczniów za najbardziej charakterystyczną cechę nauczania o zdrowiu w amerykańskich szkołach. Jego porównania i postulaty dotyczące Polski są również zbliżone do przedstawionych w omówionym wcześniej artykule. Nawet entuzjazm M. Kacprzaka - wobec amerykańskich doświadczeń w promowaniu zdrowia w wymiarze indywidualnym i społecznym przypominał miejscami zachwyt S. Szumana, gdyż podkreślał on: „Ameryka [...] imponuje pod wieloma względami [...] troska o zdrowie cieszy się poparciem tych, co rządzą i tych, co słuchają"74.

Problem nadmiernego rozbudowania programów szkolnych, ich niewłaściwej realizacji i braku zharmonizowania z właściwościami rozwojowymi uczniów stanowił wątek współwystępujący w polskiej publicystyce medycznej okresu międzywojennego z kwestią „przeciążenia szkolnego”. W związku z XII Międzynarodowym Kongresem pedagogicznym przeprowadzano w szkołach polskich ankietę mającą na celu „wyświetlenie stanu przeciążenia”. Wyniki uzyskane na drodze tego badania zostały przedstawione przez S. Kopczyńskiego w ramach obrad Kongresu Międzynarodowego Opieki nad Dzieckiem, które miały miejsce w Lizbonie w październiku 1931 r. Jeszcze wcześniej pobudziły do dyskusji lekarzy i pedagogów zastanawiających się nad wadami samej ankiety i jej wartością. Akcentowano ujawnioną wskutek badań współodpowiedzialność nauczycieli za

70 S. S z u m a n, Propaganda higieny..., s. 6.

71 Tamże, s. 7.

72 Tamże, s. 5.

${ }^{73}$ M. K a c p r z a k, Sprawy sanitarne..., s. 332-371.

74 Te nż e, Mleko..., s. 10. 
powodowanie przeciążenia szkolnego. Podkreślono interesujące aspekty czasu wolnego uczniów. Dostrzeżono potrzebę podejmowania badań nad budżetem czasu uczniów, a także powtarzania badań na temat „przeciążenia uczniów”75.

Wiele miejsca poświęcono w polskiej prasie medycznej II RP kwestiom innowacyjnych rozwiązań organizacyjnych szkół, które pojawiły się w Europie i Stanach Zjednoczonych na fali ruchu Nowego Wychowania. Miały one związek z podnoszeniem kultury zdrowotnej szkoły wyrażonej w trosce o zapobieganie chorobom u dzieci słabszych i wrażliwszych, najczęściej tych, których zdrowie było zagrożone przez trudne warunki życia, wynikające z uwarunkowań społeczno-ekonomicznych. $Z$ jednej strony więc pojawianie się tego wątku ma związek z postępem w pedagogice i tzw. ruchem reform, a z drugiej - wiąże się z rozwojem medycyny społecznej i uznaniem środowiskowych i społecznych uwarunkowań chorób.

Zarówno w relacjach z podróży po krajach Europy Zachodniej przedstawianych przez S. Kopczyńskiego, jak i w sprawozdaniu z wizyty w Stanach Zjednoczonych M. Kacprzaka znalazły się opisy "szkół na wolnym powietrzu”. Szczególne zainteresowanie S. Kopczyńskiego wzbudził właśnie ten typ szkoły przeznaczony dla dzieci zagrożonych gruźlicą, którą opisywał następująco: „[...] nieustająca szkoła-kolonia na otwartym powietrzu dla dzieci z londyńskich szkół powszechnych, czynna przez cały rok i mogąca pomieścić do 300 dzieci [...] Uderzała u tej dziatwy duża radość życia"76.

O takich szkołach na gruncie amerykańskim pisał również z entuzjazmem i zachwytem M. Kacprzak, podkreślając, że w szkołach na otwartym powietrzu „[...] całe urządzenie i system wykładów mają przede wszystkim na względzie zdrowie uczniów"77. Liczbę takich szkół w Stanach Zjednoczonych określił na ok. 3000 tys., a zlokalizowane były one na dachach domów, na statkach, a nawet w specjalnie przystosowanych mieszkaniach. Doskonale, zdaniem autora relacji, łączono w "szkołach na otwartych powietrzu” naukę, odżywianie i odpoczynek uczniów. Dla dzieci, które ważyły mniej - przez co były bardziej podatne na zachorowania - tworzone były, z kolei, specjalne klasy w szkołach normalnych z lepszą opieką medyczną, częstszymi badaniami lekarskimi, dożywianiem (zwłaszcza mlekiem). W takich klasach zwracano większą uwagę na kształtowanie nawyków i przyzwyczajeń higienicznych, a także na zabawę i odpoczynek uczniów ${ }^{78}$.

Prosty sposób na organizację „zdrowej szkoły” według Granchera polecał Karol Jonscher: „podwójna dawka powietrza, podwójna porcja odżywiania i połowa porcji pracy"79.

${ }^{75}$ Posiedzenie lekarzy szkolnych w dniu 19.02.1931 r., „Polska Gazeta Lekarska” 1931, nr 37, s. 546. Por. Przeciążenie w szkole średniej, „Nowiny Społeczno-Lekarskie” 1933, nr 9, s. 132.

76 S. K o p c z y ń s k i, Higiena szkolna i wychowanie fizyczne na Zachodzie..., s. 129.

77 M. Ka c prza k, Sprawy sanitarne..., s. 359.

${ }^{78} \mathrm{Na}$ łamach prasy lekarskiej można znaleźć informacje o powstawaniu pierwszych „szkół na wolnym powietrzu” w Polsce. W 1928 r. założono taką szkołę w Skolimowie, a w 1929 r. w Nowym Mieście n. Pilicą. Podano za: K. J o n s c h e r, Społeczna ochrona dziecka przed gruźlicą, „Nowiny Lekarskie” 1928, z. 19, s. 734; Szkoła na wolnym powietrzu, „Nowiny Lekarskie” 1929, z. 19, s. 690.

79 Te nż e, Społeczna ochrona..., s. 734. 
Również w relacjach z Norwegii prezentowanych przez płk. dra Stefana Rudzkiego przytaczane są przykłady i opisy „szkół na wolnym powietrzu”. Pojawia się tu jeszcze jedno określenie - „szkoły/szpitale morskie”. Bardzo intensywna działalność organizacji walczących z gruźlicą w Norwegii - Norweskiego Czerwonego Krzyża, Ligi Higieny Kobiet Norweskich, Narodowego Związku Przeciwgruźliczego - poprzez profilaktykę, a więc zorganizowanie kontroli mleka, powtarzane badania w kierunku gruźlicy, szczepienia i właśnie specjalne formy organizacyjne pracy szkolnej - przyniosły w efekcie w Norwegii ogromny spadek śmiertelności z powodu gruźlicy ${ }^{80}$.

Z kolei „szkoły leśne” dla zagrożonych gruźlicą uczniów drezdeńskich szkół powszechnych wywarły wielkie wrażenie na uczestniczącym w II Międzynarodowej Wystawie Higienicznej w Dreźnie K. Mitkiewiczu ${ }^{81}$.

Popularyzacji idei „osiedli szkolnych”, za propagatora których na gruncie polskim uznaje się Bogdana Nawroczyńskiego ${ }^{82}$, mógł natomiast pomóc przekaz o nich K. Mitkiewicza, który przy okazji bytności na Międzynarodowej Wystawie Higienicznej zwiedzał Osiedle Szkolne Państwowego Gimnazjum im. A. Dürera w Saskiej Szwajcarii ${ }^{83}$.

Dalsza popularyzacja idei „osiedli szkolnych” i „szkół na wolnym powietrzu” łączyła się z opublikowaniem sprawozdania z Kongresu Szkół na Wolnym Powietrzu, który miał miejsce w Brukseli w 1932 r. Bolesław Kielski - reprezentujący MWRiOP - tak relacjonował osiągnięcia Niemiec prezentowane wówczas: „Przodują one w trosce o zdrowie rasy. Tocząc walkę z ujemnymi, powojennymi warunkami młodego pokolenia i ze zgubnym wpływem ulicy na zdrowie i duszę dziecka przenoszą wychowanków wielkomiejskich szkół do tzw. „Freiluftschule” lub „Waldschule”. Liczba osiedli szkolnych („Hëim”) wynosi 250 [...]”84.

W lipcu 1936 r. uczestnikiem III Międzynarodowego Kongresu Szkół na Wolnym Powietrzu, odbywającego się w Bielefeldzie i Hannowerze był K. Mitkiewicz, który przedstawił w środowisku warszawskich lekarzy sprawozdanie z obrad i odbytych hospitacjii

80 S. R u d z k i, Walka z gruźlicą wśród dziatwy i młodzieży w Norwegii, „Polska Gazeta Lekarska" 1931, nr 3, s. 614-615; Protokół z posiedzenia lekarzy szkolnych z dnia 20 XI 1930 r., tamże, s. 59.

${ }^{81}$ Międzynarodowa Wystawa Higieniczna w Dreźnie, „Lekarz Polski” 1930, nr 2, s. 36; Z posiedzenia lekarzy szkolnych w MWRiOP, posiedzenie w dniu 18 IX 1930 r., „Wychowanie Fizyczne” 1931, nr 1, s. 30-32.

${ }^{82}$ Bogdan Nawroczyński dzięki serii odczytów i publikacji propagował w Polsce ideę „osiedli szkolnych”. W 1929 r. opublikowano jego odczyt w „Ruchu Pedagogicznym” oraz w zbiorze prac tego autora pt. Swoboda i przymus w wychowaniu. Na ten temat szerzej: W. W y r o b k o w a-P a w ł o w s ka, Wychowanie fizyczne w polskich szkołach eksperymentalnych w początkach XX w., „Kultura Fizyczna” 1967, nr 9, t. 20, s. 405-408; J. K u I w i e ć, Osiedla szkolne w latach 1928-1939, „Przegląd Historyczno-Oświatowy" 1975, nr 1, s. 83-98. Zob. też: A. R o n d t h a l e r, Osiedla szkolne, Warszawa 1933.

${ }^{83}$ Z posiedzenia lekarzy szkolnych w MWRiOP, posiedzenie w dniu 18 IX 1930 r. ..., s. 31.

${ }^{84}$ Kronika, Szkoły i klasy na wolnym powietrzu, „Wychowanie Fizyczne” 1932, nr 1-4, s. 83. Zob. też: Cz. Ka rwo w s ki, Szkoły i klasy na wolnym powietrzu, „Wychowanie Fizyczne” 1934, nr 1-2, s. 50-51

${ }^{85}$ Protokół z posiedzenia lekarzy szkolnych warszawskich w dniu 19 XI 1936 r., „Polska Gazeta Lekarska" 1937, nr 12, s. 229. 
Zainteresowanie problematyką placówek o charakterze „osiedli szkolnych”, jak i „szkół na otwartym powietrzu” pozostało intensywne do końca okresu międzywojennego ${ }^{86}$.

Klimatem psychospołecznym szkoły zajmowano się w polskim czasopiśmie medycznym w związku z udziałem Polski w międzynarodowym ruchu w dziedzinie higieny psychicznej i postępującym rozwojem higieny psychicznej w Polsce ${ }^{87}$. Rozwój ten wyrażał się utworzeniem Instytutu Higieny Psychicznej w Warszawie ${ }^{88}$ i wydawaniem czasopisma „Higiena Psychiczna”, którego pierwszy numer ukazał się w 1935 r. Na jego łamach podejmowano kwestie związane ze współtworzeniem klimatu psychospołecznego szkoły przez nauczyciela. Bronisław Biegeleisen akcentował kwestie higieny psychicznej nauczyciela przekładającej się na jakość psychospołecznego środowiska szkoły, określając optymalizację w tym zakresie w następujący sposób: „Jedną z tragedii naszego kulturalnego życia jest to, że wychowanie naszych dzieci spoczywa często w rękach osób nieszczęśliwych albo niezdolnych do harmonijnego życia. Trzeba więc podwyższyć standard życiowy w tym zawodzie, trzeba nauczycielom zapewnić spokojny byt [...] trzeba umożliwić im życie swobodne, pełne wewnętrznego zadowolenia, możliwie pozbawione trosk [...]"89. Autor artykułu powoływał się na amerykańskie opracowania z zakresu higieny psychicznej nauczyciela ${ }^{90}$. Podobne zagadnienia zawierały streszczenia artykułów z prasy amerykańskiej publikowane w czasopiśmie „Higiena Psychiczna"91.

Porównawcze studium Kazimierza Dąbrowskiego na temat rozwoju instytucji zajmujących się higieną psychiczną zagranicą i Polsce znalazło się natomiast na łamach „Lekarza Polskiego"92.

Z kolei hospitująca pracę poradni wychowawczych typu adlerowskiego w Wiedniu - Wiktoria Piotrowska - w dokształcaniu psychologicznym nauczycieli widziała sposób na poprawę atmosfery panującej szkole ${ }^{93}$.

${ }^{86}$ Za jeden z pierwszych przejawów zainteresowania tą problematyka na łamach polskiej prasy okresu dwudziestolecia międzywojennego można uznać opublikowanie streszczenia artykułu dr C. M u I o n, Szkoły i klasy na wolnym powietrzu z „Le Médicine Scolaire” w „Wychowaniu Fizycznym” 1920, nr 10-12, s. 229-230, zaś za ostatni - Szkoła leśna w kantonie Bazylea, „Oświata i Wychowanie” 1939 , z. 5, s. 514-515.

${ }^{87}$ W 1908 r. ukonstytuowało się pierwsze towarzystwo higieny psychicznej w USA, co zapoczątkowało ruch naukowo-społeczny rozszerzający się na inne kraje. W I Międzynarodowym Kongresie Higieny Psychicznej, który odbył się w 1930 r. w Waszyngtonie wzięli udział reprezentanci 53 państw. Podano za: O. Bielawski, Artykuł wstępny, „Higiena Psychiczna” 1935, nr 1-2, s. 1.

${ }^{88}$ Protokół z posiedzenia Sekcji Higieny psychicznej Państwowej Narodowej Rady Zdrowia z dnia 10.IV 1935, referat dra K. Dąbrowskiego, „Polska Gazeta Lekarska” 1936, nr 41, s. 808-809.

${ }^{89}$ B. B i e g e I e i s e n, Z higieny psychicznej nauczyciela, „Higiena Psychiczna” 1938, nr 1-2, s. 148

90 Tamże; C. B a s s e t t, The School and the Mental Health, New York 1931, s. 161.

91 Referaty: Zdrowie psychiczne nauczyciela (The Mental Health of the Teacher) - James S. Plant - St. Zjednoczone Ameryki Północnej, „Mental Hygiene” 1934, no. 1; „Higiena Psychiczna” 1935, nr 1-2, s. 77.

92 K. Dą b row s k i, Higiena psychiczna za granicą i u nas, „Lekarz Polski” 1933, nr 6-7, s. 162-168. Por. t e n ż e, Organizacja międzynarodowa higieny psychicznej, „Lekarz Polski” 1933, nr 8, s. 190-195.

93 Protokół z posiedzenia lekarzy szkolnych w dniu 21 I 1932 r., Z 1932, nr 3-4, s. 187. 
Znaczenie poradni wychowawczych dla zachowania zdrowia psychicznego uczniów poprzez oddziaływanie na nich samych, jak również na ich rodziców omówiła, konfrontując z doświadczeniami zagranicznymi, Zofia Rosenblum ${ }^{94}$.

Reasumując dokonaną analizę zawartości czasopism medycznych w II Rzeczypospolitej Polskiej, należy zauważyć, że prezentowano na ich łamach koncepcje i rozwiązania stosowane w zakresie kultury zdrowotnej szkoły w licznych krajach europejskich - najczęściej pojawiały się doświadczenia niemieckie, ale również pozaeuropejskie - tutaj na plan pierwszy wysuwa się przenikanie idei i wzorów z USA. W USA bowiem najwcześniej uformowała się akademicka pozycja zdrowia publicznego przy daleko idącej demokratyzacji szkolnictwa. Dominacja inspiracji niemieckich może natomiast łączyć się z jednej strony z bliskością geograficzną Niemiec, a drugiej - z pewną fascynacją polskich lekarzy „dążeniem do polepszenia rasy", które w tym kraju bardzo mocno przekładało się na koncepcję „zdrowa szkoła - zdrowy uczeń - zdrowy naród”. Obecność eugenicznych wątków przy uzasadnianiu konieczności podniesienia kultury zdrowotnej szkoły znajdowała wyraźne odbicie na łamach polskiej prasy medycznej. Zwiastunem tych wątków były następujące słowa odezwy do lekarzy szkolnych, którą w 1918 r. ogłosił S. Kopczyński: „Higiena szkolna to praca u podstaw nad eugeniką, nad poprawą, nad doskonaleniem fizycznem i moralnem rasy ludzkiej" ${ }^{55}$.

Pojawianie się tematyki zagranicznej poprzez porównywanie i odnajdywanie odrębności warunków funkcjonowania polskiej szkoły z doświadczeniami innych krajów pobudzało dyskusję nad stanem kultury zdrowotnej szkoły i społeczeństwa.

Wskazywanie możliwości optymalizacji kultury zdrowotnej polskiej szkoły stanowiło o aplikacyjnej wartości zagranicznych rozwiązań prezentowanych w szerokim spektrum na łamach polskiej prasy lekarskiej i higienicznej dwudziestolecia międzywojennego.

94 Z. Ros e n b I u m, Higiena psychiczna w zastosowaniu do dziecka w Europie Zachodniej i Polsce, „Warszawskie Czasopismo Lekarskie” 1935, nr 18, s. 381-384. Por. H. R. K a t z ó w n a, Psychohigiena wieku dziecięcego a błędy wychowawcze, „Higiena Psychiczna” 1936, nr 4-7, s. 209219; L. G o r y ń s k i, Opieka higieniczno-psychiczna nad dziećmi w Polsce, „Biuletyn Instytutu Higieny Psychicznej" 1938, nr 1.

95 S. K o p c z y ń s k i, Lekarz szkolny i opieka lekarska w szkole, [w:] Higiena szkolna. Podręcznik..., s. 567. Por. też: T. J a n i s z e w s k i, Społeczne...; J. B a b e c k i, Opieka... 